for the development of transient tachypnoea of the newborn.

Recent studies indeed showed the beta adrenergic system as having an important role in the increased fluid absorption as well as the decreased fluid production occurring after birth. ${ }^{5}$ In addition, a relationship between asthma and beta adrenergic system malfunction was suggested by the reduction in the number of lymphocytic beta adrenoreceptors in bronchial asthma causing overall subsensitivity in this system. This appears to be fundamentally characteristic of atopy and is associated with a concurrent increase in alpha ${ }_{2}$ adrenergic receptors. The degree of reduction in the lymphocytic beta receptor number correlates well with the disease severity and airway obstruction. ${ }^{6}$ Therefore, beta adrenergic malfunction, which is associated with both delayed fluid reabsorption in the newborn and asthma, may be one of the common pathogenic mechanisms.

In this retrospective study mothers were interviewed in order to obtain the maximum information possible regarding the incidence of symptoms suggestive of childhood asthma. Our study suggests that there is a significant increase in the incidence of childhood asthma in infants with transient tachypnoea of the newborn. A prospective study will be helpful in further establishing this relationship, as well as their association to the beta adrenergic system malfunction.

We gratefully acknowledge Drs M Nitzan, SH Reisner, and C Springer for their help and important comments. We thank Daune Thorington for her excellent secretarial help. This work was supported in part by Shriber Fund, Sackler School of Medicine, Tel Aviv University, Israel.

This work was submitted as part of the requirements for the MD degree of Dr G Levy.

\section{References \\ 1 Avery ME, Gatewood OB, Brumley G. Transient tachypnea of newborn, possible delayed resorption of fluid at birth. Am J Dis Child 1966;111:380-5. \\ 2 Rimmer S, Fawcitt J. Delayed clearance of pulmonary fluid in the neonate. Arch Dis Child 1982;57:63-7. \\ ${ }^{3}$ Shohat M. Diagnosis, management, and prognosis of asthma in children. Comprehensive Therapy 1987;13:7-13. \\ ${ }^{4}$ Lagercrantz H, Bistoletti P. Catecholamine release in the newborn infant at birth. Pediatr Res 1973;11:889. \\ ${ }^{5}$ Wyszogrodski I, Taeusch HW Jr, Avery ME. Isoxuprine- induced alterations of pulmonary pressure-volume relationships in premature rabbits. Am J Obstet Gynecol 1974;119:1107. \\ ${ }^{6}$ Barnes PJ. Endogenous catacholamines and asthma. J Allergy Clin Immunol 1986;77:791-5.}

Correspondence to Dr M Shohat, Department of Pediatrics, Cedars-Sinai Medical Center, 8700 Beverly Boulevard, Los Angeles, CA 90048, USA.

Accepted 16 August 1988

\title{
Evaluation of two combined oxygen and carbon dioxide transcutaneous sensors
}

\author{
H K LEE, E BROADHURST, AND P HELMS \\ Respiratory Unit, Hospital for Sick Children, Great Ormond Street, London
}

SUMMARY Two combined oxygen and carbon dioxide electrodes were assessed in neonates, infants, and children up to 16 years. They were convenient to use and the measurement error for $\mathrm{PtcCO}_{2}$ was acceptable. In both models, however, the $\mathrm{PtcO}_{2}$ electrode had a reduced performance compared with a single electrode.

Transcutaneous measurements of oxygen and carbon dioxide $\left(\mathrm{PtcO}_{2}, \mathrm{PtcCO}_{2}\right)$ are useful in the intensive care unit because they provide continuous and non-invasive monitoring of gas exchange. $\mathrm{PtcO}_{2}$ underestimates arterial oxygen $\left(\mathrm{PaO}_{2}\right)$ because of the skin diffusion barrier and $\mathrm{PtcCO}_{2}$ overestimates arterial carbon dioxide $\left(\mathrm{PaCO}_{2}\right)$ because of skin carbon dioxide production. ${ }^{1}$ Various methods of 'arterialising' $\mathrm{PtcO}_{2}$ and $\mathrm{PtcCO}_{2}$ by appropriate adjustment at calibration have been described..$^{2-4}$

Until recently, $\mathrm{PtcO}_{2}$ and $\mathrm{PtcCO}_{2}$ sensors consisted of two electrodes that were each calibrated and applied separately. The introduction of combined oxygen and carbon dioxide electrodes in a single probe has obvious advantages, and previous reports in newborn infants ${ }^{5}$ and adults ${ }^{6}$ have suggested an accuracy comparable with separate oxygen and carbon dioxide electrodes.

We therefore assessed two commercially available combined oxygen and carbon dioxide electrodes in infants and children beyond the neonatal period using calibration correction factors obtained from previous studies with single electrodes. ${ }^{34}$ 


\section{Methods}

A total of 18 patients from the general intensive care unit were studied. Their median age was 1.4 years with a range from 2 weeks to 16.5 years. All patients had indwelling arterial catheters and were haemodynamically stable with satisfactory blood pressure and peripheral-core temperature gradients of less than $5^{\circ} \mathrm{C}$. Informed consent was obtained from the parents of the children and the study had the approval of the hospital ethical committee.

The Kontron MicroGas 7640 with COMBI Sensor and the Radiometer TCM3 with E5277 sensor were used. The Kontron machine uses two gas calibrations (gas $1: 20.6 \%$ oxygen, $5 \%$ carbon dioxide; gas $2: 10 \%$ carbon dioxide) while the Radiometer machine uses one gas only $(20.9 \%$ oxygen, $5 \%$ carbon dioxide). Blood gas measurements were performed using an analyser (IL 1306, Instrumentation Laboratories) that was calibrated daily with reference solutions (Certain Corning).
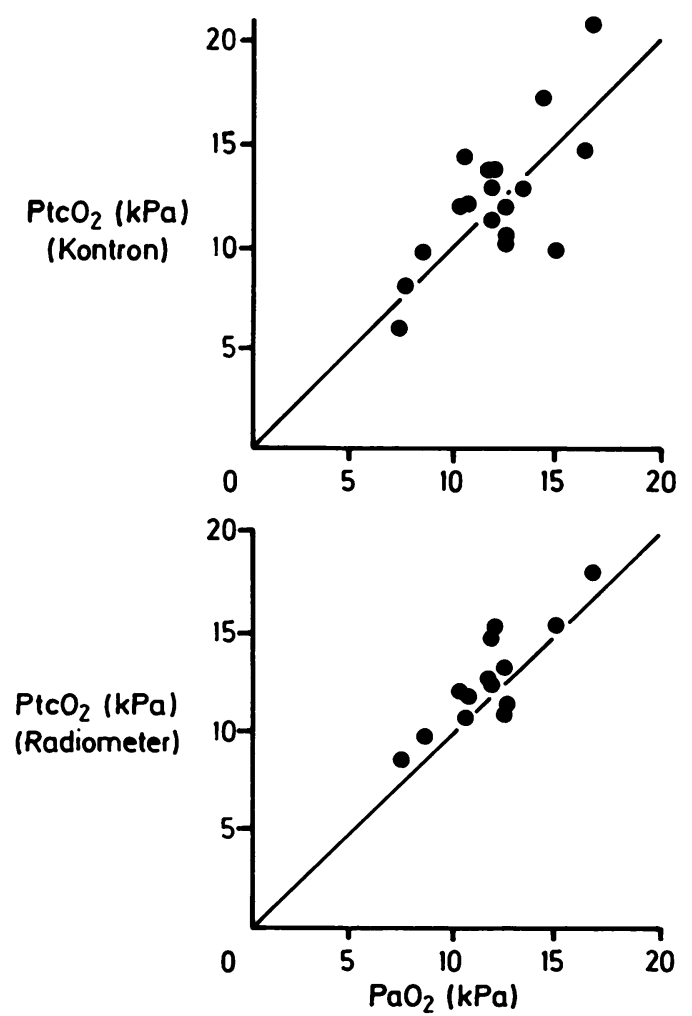

During the course of the study reference solutions for oxygen and carbon dioxide recorded small negative biases (means -0.17 and $-0.05 \mathrm{kPa}$ respectively). The errors (SD) were also small, although larger for oxygen than for carbon dioxide; 0.38 and 0.06 respectively.

The following calibration technique was used to make the transcutaneous readings reflect the arterial gas values (based on previous studies) ${ }^{3}$ : (1) $\mathrm{PtcO}_{2}$ was adjusted to read $25.6 \mathrm{kPa}$ in air (a correction factor of 1.22). (2) $\mathrm{PtcCO}_{2}$ was adjusted to read $3 \cdot 54$ $\mathrm{kPa}$ in $5 \%$ carbon dioxide and $7.07 \mathrm{kPa}$ in $10 \%$ carbon dioxide (a correction factor of 0.714 ).

The two different sensors were placed side by side on the upper anterior chest and the temperature set to $44^{\circ} \mathrm{C}$. Transcutaneous readings and simultaneous arterial samples were taken at 30 minutes, 11/2 hours, and $4 \frac{1}{2}$ hours after electrode placement avoiding periods of physiotherapy and nursing or medical procedures. The sensor sites were examined immediately after sensor removal and after 24
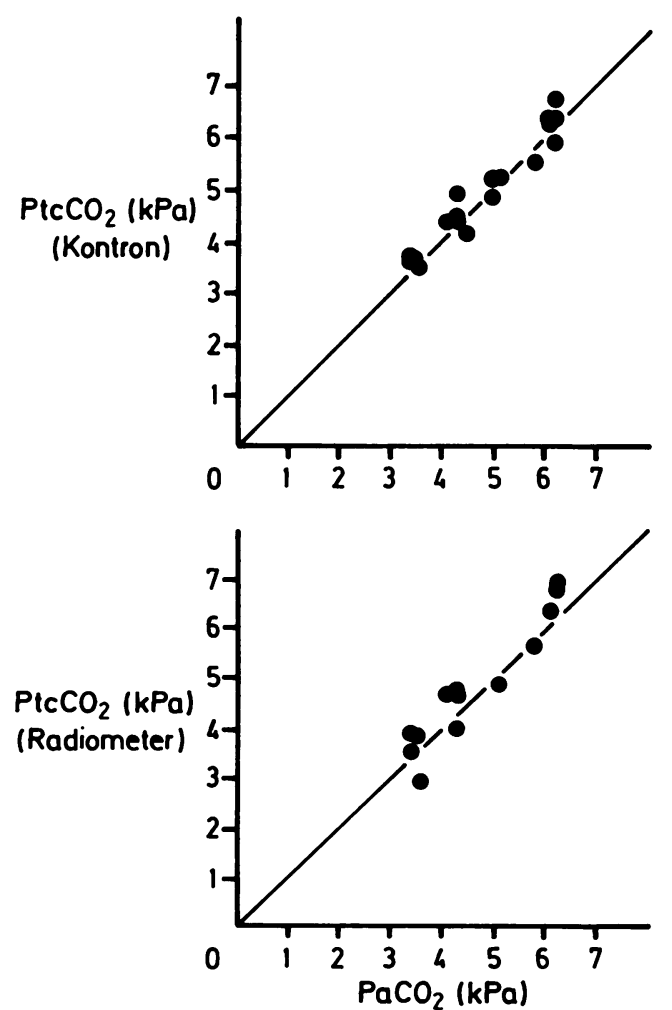

Figure Scatter plots of transcutaneous against arterial values at 11/2 hours after electrode placement. The lines of identity are drawn and both transcutaneous sensors were calibrated with appropriate correction factors. ${ }^{34}$ Note the larger scatter (error) for the Kontron machine for $\mathrm{PtcO}_{2}$ and the small positive biases for all transcutaneous measurements. 
hours. The sensors were also checked for any drift in the calibration values at the end of the $4 \frac{1}{2}$ hour period of measurement.

Arterial values were subtracted from the corresponding transcutaneous values to obtain the errors of prediction of $\mathrm{PaO}_{2}$ and $\mathrm{PaCO}_{2}$. From these, the mean errors, the standard deviation, and the $95 \%$ confidence intervals of the errors were calculated.

\section{Results}

$\mathrm{PaO}_{2}$ ranged from $6.5 \mathrm{kPa}$ to $21.3 \mathrm{kPa}$. The mean error of $\mathrm{PtcO}_{2}$ prediction of $\mathrm{PaO}_{2}$ was small for both machines and ranged from +0.1 to $+1.4 \mathrm{kPa}$ but the scatter of data around the mean was large with $95 \%$ confidence intervals of $\mathrm{PaO}_{2}$ prediction for both machines ranging from $-5.59 \mathrm{kPa}$ to $7.67 \mathrm{kPa}$ (table).

$\mathrm{PaCO}_{2}$ ranged from $2 \cdot 8 \mathrm{kPa}$ to $6 \cdot 8 \mathrm{kPa}$. The mean error of prediction of $\mathrm{PaCO}_{2}$ and the scatter were less than that for $\mathrm{PaO}_{2}$ and both machines were of very similar performance (table).

With respect to $\mathrm{PtcO}_{2}$, the drift of the calibration value after $4 \frac{1}{2}$ hours for the Kontron machine was +2.9 with a $95 \%$ confidence interval of $-2 \cdot 1$ to 7.9 $\mathrm{kPa}$. The corresponding mean $(95 \%$ confidence interval) calibration drift for the Radiometer machine was less at $+1 \cdot 0(-2 \cdot 1$ to $4 \cdot 1) \mathrm{kPa}$. The drifts for $\mathrm{PtcCO}_{2}$ were small for both machines 0 $(-0.4$ to 0.4$) \mathrm{kPa}$ and $-0.2(-0.5$ to 0.1$) \mathrm{kPa}$ for Kontron and Radiometer machines respectively. No burns were noted for either sensor and any erythema had disappeared within 24 hours. Both machines were easy to calibrate, although the calibration of the Radiometer was faster than for the Kontron machine as the former only required one point calibration.

Both sensors were easy to apply. The Radiometer sensor had one advantage in that it could be temporarily removed for nursing procedures and could then be reapplied by simply screwing it onto the adhesive ring which remained attached to the skin.

\section{Discussion}

The mean biases in $\mathrm{PaO}_{2}$ and $\mathrm{PaCO}_{2}$ prediction were generally small, which suggests that the use of 'correction factors' at calibration is valid. The biases were all positive, however, suggesting that previously derived correction factors may need further refinement for newer machines. This seems reasonable as one might expect small differences between machines of different type and design.

Although the mean data showed a small positive bias, what is more relevant for clinical use are the errors of measurement. For $\mathrm{PtcO}_{2}$ prediction of $\mathrm{PaO}_{2}$ these errors were large particularly for the Kontron machine (table). The measurement error of the blood gas machine was also larger for oxygen than for carbon dioxide as identified at daily calibration. These errors were very small at $95 \%$ confidence intervals of -0.46 to $0.30 \mathrm{kPa}$ for oxygen and -0.04 to $0.08 \mathrm{kPa}$ for carbon dioxide, however, and did not explain the much greater disparity between the performance of the transcutaneous sensors (table).

We also found large drifts in calibration values after $4 \frac{1}{2}$ hours with respect to $\mathrm{PtcO}_{2}$ with the Kontron machine performing less well than the Radiometer. These drifts were larger than the values quoted in the specification of both models supplied by the manufacturers: Kontron, $<3 \% 4$ hours; Radiometer, $<0 \cdot 13 \mathrm{kPa} /$ hour. The measurement errors and the drifts were larger than those found in previous studies using a single $\mathrm{PtcO}_{2}$ electrode $^{3}$ and must question the clinical usefulness of $\mathrm{PtcO}_{2}$ from these combined electrodes.

For $\mathrm{PtcCO}_{2}$, both machines showed acceptable

Table Errors found on the two machines

\begin{tabular}{|c|c|c|c|c|c|}
\hline \multirow[t]{2}{*}{ Time after placement } & \multirow{2}{*}{$\begin{array}{l}\text { No of } \\
\text { assessments }\end{array}$} & \multicolumn{2}{|l|}{ Kontron } & \multicolumn{2}{|l|}{ Radiometer } \\
\hline & & $\begin{array}{l}\text { Mean error } \\
(k P a)\end{array}$ & $\begin{array}{l}95 \% \text { confidence } \\
\text { interval }(\mathrm{kPa})\end{array}$ & $\begin{array}{l}\text { Mean error } \\
(\mathrm{kPa})\end{array}$ & $\begin{array}{l}95 \% \text { confidence } \\
\text { interval }(\mathrm{kPa})\end{array}$ \\
\hline \multicolumn{6}{|c|}{ Errors in estimating $\mathrm{PaO}_{2}$ from $\mathrm{PtcO}_{2}$} \\
\hline $\begin{array}{l}30 \text { minutes } \\
11 / 2 \text { hours } \\
41 / 2 \text { hours }\end{array}$ & $\begin{array}{l}18 \\
18 \\
14\end{array}$ & $\begin{array}{l}+0.13 \\
+0.45 \\
+1.41\end{array}$ & $\begin{array}{l}-5.59 \text { to } 5.85 \\
-4.40 \text { to } 5 \cdot 30 \\
-4.85 \text { to } 7.67\end{array}$ & $\begin{array}{l}+0.64 \\
+0.97 \\
+0.74\end{array}$ & $\begin{array}{l}-4.31 \text { to } 5.59 \\
-1.75 \text { to } 3.69 \\
-5.16 \text { to } 6.64\end{array}$ \\
\hline \multicolumn{6}{|c|}{ Errors in estimating $\mathrm{PaCO}_{2}$ from $\mathrm{PtcCO}_{2}$} \\
\hline $\begin{array}{l}30 \text { minutes } \\
11 / 2 \text { hours } \\
41 / 2 \text { hours }\end{array}$ & $\begin{array}{l}18 \\
18 \\
14\end{array}$ & $\begin{array}{l}+0 \cdot 18 \\
+0 \cdot 22 \\
+0 \cdot 22\end{array}$ & $\begin{array}{l}-0.50 \text { to } 0.86 \\
-0.33 \text { to } 0.77 \\
-0.51 \text { to } 0.95\end{array}$ & $\begin{array}{l}+0.50 \\
+0.30 \\
+0.07\end{array}$ & $\begin{array}{l}-0.13 \text { to } 1.13 \\
-0.51 \text { to } 1.11 \\
-0.62 \text { to } 0.76\end{array}$ \\
\hline
\end{tabular}


and comparable results. Although Kontron uses two point calibration, this did not show any advantage over the one point calibration used by Radiometer. The errors and drifts compared favourably with a previous study using a single Kontron $\mathrm{PtcCO}_{2}$ electrode. ${ }^{3}$

In summary, the combined electrodes we assessed do offer the advantage of convenience of use, and the measurement error for $\mathrm{PtcCO}_{2}$ is clinically acceptable. In both the models we assessed, however, miniaturisation of $\mathrm{PtcO}_{2}$ electrode appears to have reduced its performance when compared with single electrodes. Improvements in performance in the oxygen sensor part of these combined probes would be desirable.

\section{References}

${ }^{1}$ Severinghaus J, Stafford M, Thurnstrom A. Estimation of skin metabolism and blood flow with $\mathrm{TcPO}_{2}$ and $\mathrm{TcPCO}_{2}$ electrodes by cuff occlusion of the circulation. Acta Anaesthesiol Scand 1978;68:(suppl) 99-105.

2 Monaco F, McGuitty JC, Nickerson BG. Calibration of a heated transcutaneous $\mathrm{CO}_{2}$ electrode to reflect arterial $\mathrm{CO}_{2} . \mathrm{Am} R e v$ Respir Dis 1983;127:322-4.

3 Cheriyan G, Helms P, Paky F, Marsden D, Chiu MC. Transcutaneous estimation of arterial carbon dioxide in intensive care. Arch Dis Child 1986;61:652-6.

4 Vyas H, Helms P, Cheriyan G. Transcutaneous oxygen monitoring beyond the neonatal period. Crit Care Med 1988;16:844-7.

5 Whitehead MD, Lee BVW, Pagdin TM, Reynolds EOR. Estimation of arterial oxygen and carbon dioxide tensions by a single transcutaneous sensor. Arch Dis Child 1985;60:356-9.

6 Mahutte CK, Michiels TM, Hassell KT, Trueblood DM. Evaluation of a single transcutaneous $\mathrm{PO} 2-\mathrm{CO} 2$ sensor in adult patients. Crit Care Med 1984;12:1063-6.

Correspondence to Dr P Helms, Respiratory Unit, Hospital for Sick Children, Great Ormond Street, London WC1N 3JH.

Accepted 12 June 1988

\section{Meetings in 1989}

\section{British Paediatric Association}

11-14 April, York, England

Further details: Miss RJ Topping, Conference Secretary, British Paediatric Association, 5 St Andrew's Place, Regent's Park, London NW1 4LB

Ambulatory Pediatric Association

1-5 May, Washington DC, USA

Further details: Marge Degnon, 6728 Old McLean

Village, McLean, VA 22101, USA

\section{Clinical Genetics Society}

\section{0-31 March, Southampton}

November, London (dates and venue to be decided)

Further details: Professor NC Nevin, Department of Medical Genetics, Floor A, Tower, Belfast City Hospital, Northern Ireland

European Society for Paediatric Gastroenterology and Nutrition (ESPGAN)

31 May-2 June, Budapest, Hungary

Further details: Dr István Kósnai, 1st Department of Paediatrics, Semmelweis University Medical School, 1083 Budapest, Bókay János u 53, Hungary

\section{European Society for Pediatric Research}

11-14 June, Kraków, Poland

Further details: Dr Jacek J Pietrzyk, 1st Department of Pediatrics, Institute of Pediatrics, 30-663 Kraków, Wielicka 265, Poland

European Paediatric Respiratory Society 10-14 September, Freiburg, West Germany

Further details: Dr J Warner, Brompton Hospital, Fulham Road, London SW3 6HP

\section{Neonatal Society}

23 February, London

14-15 July, Liverpool

Further details: Professor RWI Cooke, Regional Neonatal Intensive Care Unit, Liverpool Maternity Hospital, Oxford Street, Liverpool L7 7BN 